\title{
超音波センサを用いた広域屋内測位システムの構成と検証実験
}

\author{
秋山 征己*，須永 光 ${ }^{* *}$ ，五百蔵 重典 ${ }^{* * *}$ ，田中 博**a)
}

\section{Composition and Verification Experiment for Indoor Positioning System using Ultrasonic Sensors} Masaki AKIYAMA*, Hikaru SUNAGA ${ }^{* *}$, Shigenori IOROI ${ }^{* * *}$, Hiroshi TANAKA $^{* * * a)}$

\begin{abstract}
あらまし 超音波センサを用いた測位システムは, 測位エリアの制約はあるものの高精度な測位が可能であり, 一般に屋外に比べて 高い測位精度が要求される屋内での利用に有利である. 本論文では逆 GPS 法とよばれる手法による超音波測位システムを実用的なも のとすることを目的に, 測位エリアの広域化と複数の測位対象の収容を可能と寸るための方法と構成について検討し, 検証のための試 作と評価を行った結果を述べる. 静止物体および移動物体を用いた測位精度評価実験の結果, 測位誤差が最大でも $100 \mathrm{~mm}$ 以下に抑 えられており, 要求精度を十分に満足していることを示す.さらに応用例として移動ロボットを用いて歩行者ナビゲーションを想定した模 擬実験を行い, システムの有用性を確認した結果を示す.
\end{abstract}

Abstract Positioning systems that use ultrasonic sensors can measure position with a high degree of accuracy. For this reason, they are an attractive option for use in indoors, where the level of accuracy required is higher than that needed outdoors. This study aims to make possible a practical ultrasonic positioning system based on what is called an inverse GPS method. To be practical, positioning systems should be able to cover a wide area and identify the positions of multiple objects. This paper discusses the positioning methodology and system structure to achieve these objectives. It presents the results of verification tests with static and moving objects conducted using an experimental model. It was confirmed that the positioning error is less than $100 \mathrm{~mm}$, and that the proposed system satisfies the required accuracy. In addition, as a possible application of the method, an experiment in 'pedestrian navigation' was conducted using a moving robot, and the effectiveness of the proposed system was confirmed.

キーワード 屋内測位, 超音波, 逆 GPS, エリア拡大, 複数識別

Keyword Indoor Positioning, Ultrasonic, Inverse GPS, Area Expansion, Multiple Discrimination

\section{1. まえがき}

位置情報は, 現在広く普及しているカーナビゲーション をはじめ, 場所に応じた情報の送信など, 多くのアプリケ ーションに適用される有意な情報である. 屋外における測 位方式として GPS が標準となり, 広く普及している。一 方，屋内での測位方法は多くの手法が提案されているが, 現段階では確立されているものはない. 屋内における各種 測位方式[1][2]を図 1 に示す. 無線 LAN などの電波強度 （RSSI）や受信時間（TOA）を用いる方法は, 測位範囲 は広いが測位精度が数 $\mathrm{m}$ 程度であり, 特に都市部や屋内 環境ではマルチパスによる測位精度の低下が問題となる。

* 神奈川工科大学大学院 情報工学専攻 于243-0292 神奈川県厚木市下荻野 1030

Course of Information and Computer Sciences, Graduate School of Kanagawa Institute of Technology, 1030 Shimo-ogino, Atsugi city, Kanagawa, 243-0292.

** 株式会社ジャパンプランニング

于244-0803 神奈川県横浜市戸塚区平戸町 735-3

Japan Planning Co.,Ltd, 735-3 Hirado-cho, Totsuka ward, Yokohama city, Kanagawa, 244-0803.

****神奈川工科大学 情報学部 情報工学科

于243-0292 神奈川県厚木市下荻野 1030

Department of Information and Computer Sciences, Kanagawa Institute of Technology, 1030 Shimo-ogino, Atsugi city, Kanagawa, 243-0292.

a) h_tanaka@ic.kanagawa-it.ac.jp

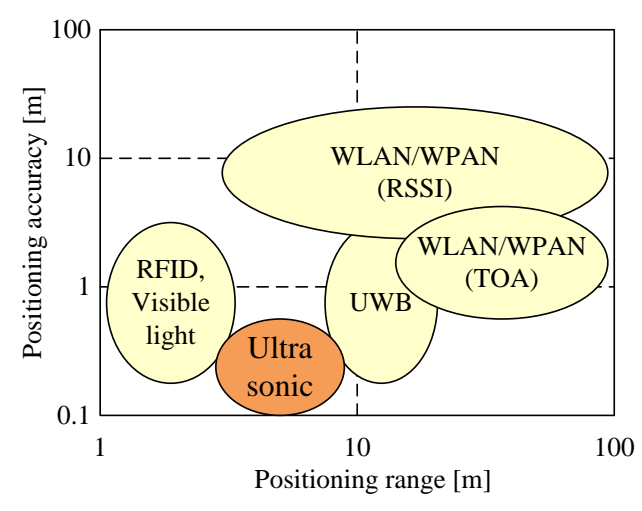

図 1 屋内における各種測位方式

Fig. 1 Categories of indoor positioning system

また，RFID や可視光通信をベースとした方法では位置特 定がその通信範囲内外の区別によるため 1 台の受信機で の測位範囲は数 $100 \mathrm{~mm}$ 数 $\mathrm{m}$ 程度である. IMES も屋内 測位で有効な手段であるものの, 数 $\mathrm{m}$ 程度の精度での測 位を目的として開発が行われている[3][4]. その中で超音 波を用いる方法は, 測位範囲が数 $\mathrm{m} \sim 10 \mathrm{~m}$ と比較的狭いも のの, 測位精度は 数 $\mathrm{mm}$ 数 $100 \mathrm{~mm}$ 程度であり, 特に屋 内における歩行者のナビゲーションなどに有効な手段に なると考えられる.また, 必要となる回路要素も電波を用 いる方法と比べて単純なもので構成できるという特長が ある。 
我々は，これまで屋内での位置測定手段として，構成の 単純化が可能であり, 電波法の制約を受けずに高精度な測 位が期待できる超音波を用いた測位システムを検討, 試作 し，その実現性や測位精度を確認してきた[5][6]. 超音波 を用いた測位システムとしては, 従来提案されている MIT[7]やケンブリッジ大学[8]の方法があり, 我が国でも 商用化されているもの[9]がある。これらは電波信号を併 用して超音波送受信機間の時刻同期を確保したり, あるい は, 電波と超音波の伝搬時間差をもとに測位計算を行うた め, 送受信機の構成が複雑になってしまう問題があった. これに対して, 我々の検討しているシステムは逆 GPS 法 とよばれる手法[10]を適用し, 電波を用いずに測位を実現 することを特徴とし, 医療施設や電磁干渉の影響を受けや すい機器周辺でも制約なく測位を実現することができる.

本論文では，逆 GPS 法による超音波を用いた屋内測位 システムについて, 実利用を可能とするために複数の測位 対象の識別および測位領域の拡大に容易に対応できる方 式を検討し, 実際に検証システムを試作して実験によって 測位精度と機能を確認した結果を述べる．さらに, 移動口 ボットを用いて歩行者のナビゲーションを想定した模擬 実験を行い, システムの有用性を確認した結果について述 ベる.

\section{2. 提案システムの適用領域と要求条件}

2.1 適用領域 屋内における測位システムの適用領域と して想定される応用例を図 2 に示す. 歩行者の位置測定か ら動線を把握し, 地下商店街や博物館などの公共空間内で の場所に応じた情報の提示や, 視覚障がい者を対象とした 音声ナビゲーションへの応用が考えられる. また, 工場内 での FA ロボットの制御への適用も考えられる.さらに, 本システムは電波を用いないため, 病院内での医師の所在 把握や点滴などの医療機材の管理への適用にも有利であ ると考えられる.

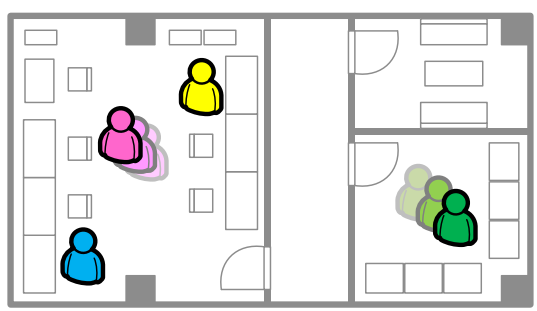

Position detection

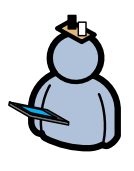

Information reception

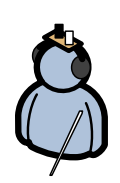

Navigation for visual impairment

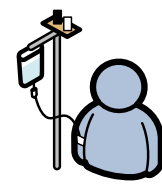

Medical equipment management, etc.
図 2 提案システムの適用領域

Fig. 2 Application area of proposed system
2.2 要求条件 図 2 で示した適用領域での利用を想定し たときの測位システムへの要求条件について述べる. 屋内 での歩行者への情報提示やナビゲーションへの適用を実 現するには, 壁との位置関係把握や衝突回避が必要となる ことから, 測位対象の占有領域よりも小さい，数 $100 \mathrm{~mm}$ 以内の測位精度が求められるとともに, 広域なエリアの測 位要求に柔軟に対応可能なアーキテクチャであることが 求められる. また，エリア内に複数の測位対象が存在する ことが必然と考えられ，この観点から複数の測位対象の識 別機能を具備することが求められる. さらに, 設置コスト の観点から測位対象に設置する機器はできるだけ小型か つ安価であること, また環境中に設置する機器は小型で取 り付けが容易な構成であることが望ましい.

\section{3. システム設計}

3.1 測位原理と識別方法 従来の超音波測位システムで は, 電波と超音波の伝搬時間差や, 送受信機間のタイミン グを同期させて超音波の伝搬時間を求めることによって, 三辺測量の原理で測位を行っている。これに対し，我々は 電波を利用せずに超音波のみで測位を行う逆 GPS 法を適 用している。 その基本原理を図 3 に示す。

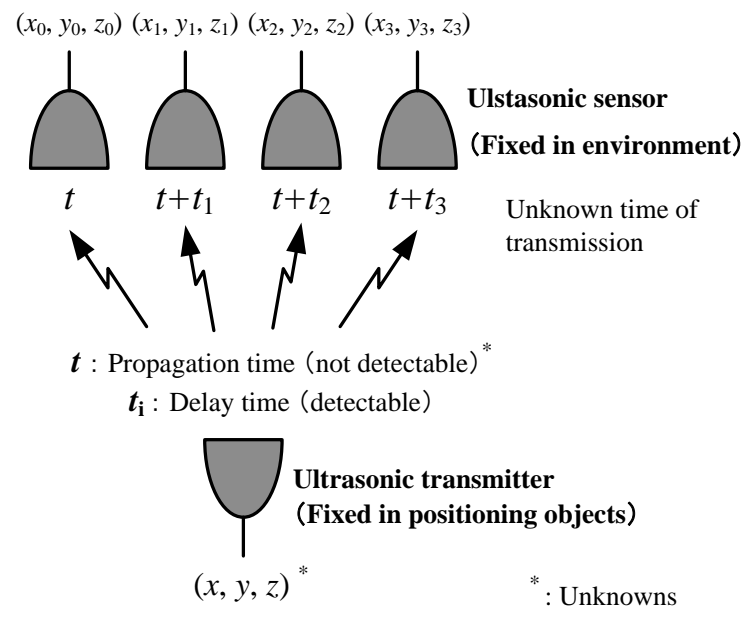

図 3 測位の基本原理

Fig. 3 Basic positioning principle

逆 GPS 法では，送受信機間のタイミングは非同期であ る。そのため超音波の伝搬時間は測定不能であり，送受信 機間の距離は直接算出できず，三辺測量は適用できない. しかし，受信センサを複数設置し，受信機間の時刻同期を 確保した場合の各センサ間の超音波受信時間差は計測可 能であり，以下の式が成り立つ。

$$
\begin{aligned}
& \sqrt{\left(x-x_{0}\right)^{2}+\left(y-y_{0}\right)^{2}+\left(z-z_{0}\right)^{2}}=c t \\
& \sqrt{\left(x-x_{1}\right)^{2}+\left(y-y_{1}\right)^{2}+\left(z-z_{1}\right)^{2}}=c\left(t+t_{1}\right) \\
& \sqrt{\left(x-x_{2}\right)^{2}+\left(y-y_{2}\right)^{2}+\left(z-z_{2}\right)^{2}}=c\left(t+t_{2}\right) \\
& \sqrt{\left(x-x_{3}\right)^{2}+\left(y-y_{3}\right)^{2}+\left(z-z_{3}\right)^{2}}=c\left(t+t_{3}\right)
\end{aligned}
$$


ここで, 送信機から超音波を最初に受信したセンサ間の 伝搬時間 $t$ と測位対象となる送信機の位置 $(x, y, z)$ は未 知の值である。一方, 各センサ間の受信時間差 $t_{i}$ および 音速 $c$ は計測可能であり, また, 各センサの設置位置 $\left(x_{i}\right.$, $\left.y_{i}, z_{i}\right)$ は既知の值である. したがって $t_{i}$ を計測して 式(1) の非線形連立方程式を解くことによって, 測位対象となる 送信機の位置を求めることができる[11].

逆 GPS 方式では, 三辺測量と異なり $t$ が加わって未知 数が 4 つとなることから, 測位計算のためには最低 4 個の センサが必要となる.このため, 三辺測量と比べてセンサ の設置個数が増加するが, 送受信機間の時刻同期が不要で あるため, 各装置の構成はより単純化することができる.

複数の対象を測位する方法として, スペクトル拡散によ って超音波を多重化する方法[12]や，超音波以外の識別信 号によって対象ごとに時分割で測位する方法などが研究 されている.スペクトル拡散では超音波の変復調に特別な ハードウェアや計算処理が必要となる. また, 従来の三辺 測量方式では, 送受信機間の同期に用いる電波に識別信号 を重畳することで複数対象の測位を実現することが可能 であるが，逆 GPS 法では電波を用いないため，別の通信 手段が必要となる. 本研究では, 簡易な部品構成で通信が 実現できる赤外線を識別信号として用いることで, 複数 対象の測位を行うこととした.

3.2 基本構成と測位シーケンス 要求条件と測位原理を 踏まえた検証システムの基本構成を図 4 に示す. 検証シス テムは, 測位対象に取り付ける超音波送信部（Ultrasonic transmit unit), 環境中に設置して赤外線の送信と超音波の 受信を行う超音波受信部（Ultrasonic receive unit）, システ ム全体の制御と測位計算を行う処理用 PC の 3 つの要素か ら構成する.

各要素の基本的な機能ついて述べる. 超音波送信部は測位 対象に取り付ける小型の装置で, 識別のためにそれぞれユ ニークな ID 割り当てる. 超音波送信部は自身の ID と

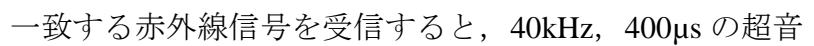

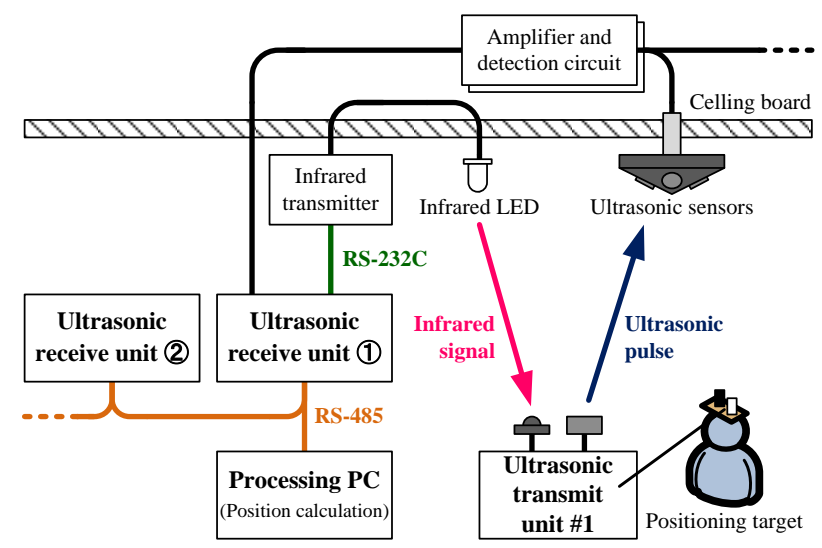

図 4 検証システムの基本構成

Fig. 4 Basic configuration of experimental system
波パルスを出力する.

超音波受信部は屋内天井に複数設置した超音波センサ, センサ信号を増幅・検波する受信回路, 各センサの受信夕 イミングをキャプチャする FPGA，赤外線信号を送信する ための赤外線送信装置, そして処理用 PC とのインタフェ 一スを確保するマイコンで構成する。検証システムでは, 測位エリアの広域化を実現するため FPGA を用いること によって受信部 1 台あたりの接続センサ数を最大 $70 \mathrm{ch}$ と し, さらに複数の超音波受信部を RS-485 でデイジーチェ ーン状にバス型接続することで, 受信機同士の時刻同期と 測位エリアの桩大が容易に可能な構成とした. なお, デイ ジーチェーン接続による信号遅延は非常に小さいため, 測 位精度に与える影響は無視することができる.

処理用 PC は一般的なパーソナルコンピュータを用い, 超音波受信部に対して赤外線出力要求, データ要求 (超音 波の受信タイミングであるカウント值や室温情報など)を 行う。そして，3.1節で述べた測位計算を行い，その結果 をリアルタイムに出力する.

検証システムにおける測位処理のシーケンスを図 5 に 示す．はじめに，処理用 PC から超音波受信部に対して測 位対象の ID を含む送信要求を出力する．なお，現状では ID は総当たりとなるように, 送信要求ごとに ID を 1 ずつ 加算していくこととした. 超音波受信部はこの要求を受け 取るとID を重畳した赤外線信号を送信し，超音波の受信 タイミング取得のための内部カウンタをスタートさせる.

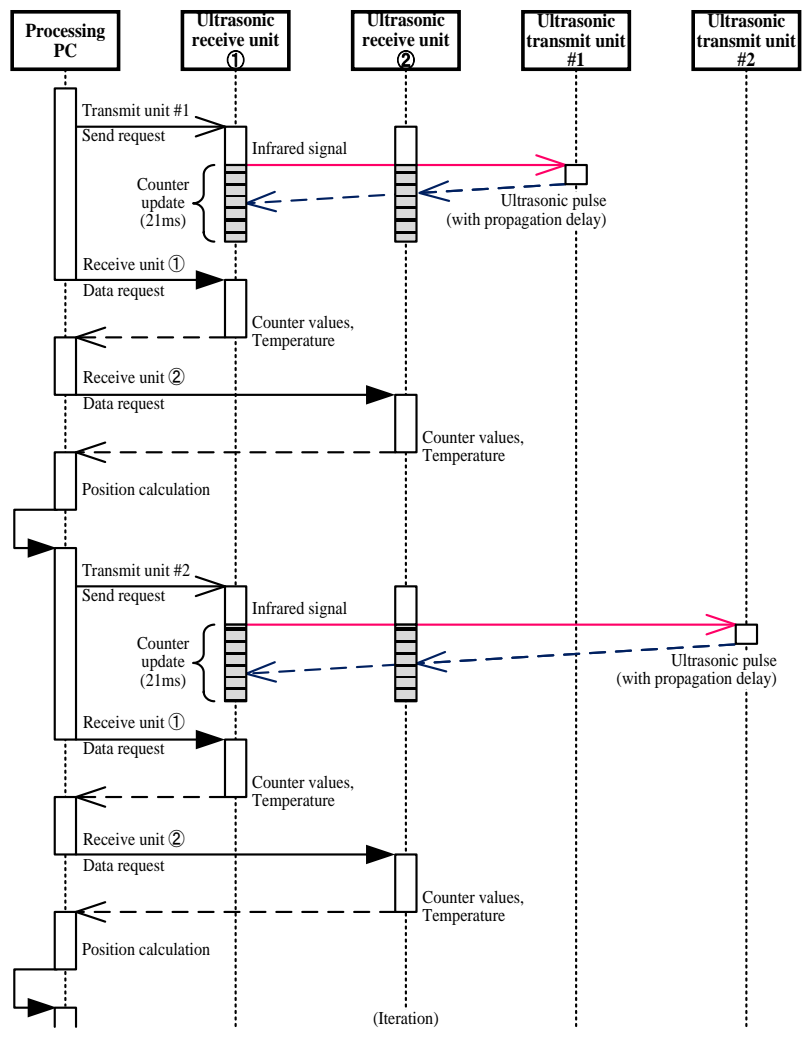

図 5 システムシーケンス

Fig. 5 System sequence 
測位対象の超音波送信部は，自身の ID と一致する赤外 線信号を受信すると超音波パルスを出力する.このパルス を天井に複数設置した受信センサで検出し, 増幅・検波回 路を介して FPGA に入力する. FPGA ではセンサチャネル ごとに超音波を検出した瞬間の内部カウント值のキャプ チャを行う。一定時間経過後, 処理用 PC は超音波受信部 でキャプチャしたカウント值と, サーミスタによって計測 した音速補正用の室温值を取得する。 そして, 取得したデ 一タをもとにして処理用 PC 上で式(1)に示寸測位計算を 行う. システム側が測位計算を行い, 各測位対象の位置情 報を保持する構成であるため, 端末側での計算処理や位置 情報の送信は必要としない。このため, 場所に応じた情報 提供や地図情報と組み合わせたナビゲーションなどに容 易に対応することが可能である.

3.3 超音波送信部の設計と実装 超音波送信部の内部構 成を図 6 に示す.超音波送信部は赤外線受信モジュールと 超音波トランスミッタ（村田 MA40S4S）, マイコン

(Microchip PIC10F222）で構成し，人や移動ロボットなど の測位対象に取り付けることを考慮して図 7 に示すよう な小型軽量な装置を試作した. 現段階では単三型充電池を 用いているが，実利用ではコイン型電池を用いることで 数 $\mathrm{cm}$ 程度のサイズにすることが可能である. また, 超音 波の到達距離を確保するため昇圧 IC でマイコンの出力信 号を増幅し, 図 8 に示寸ような $40 \mathrm{kHz}, 400 \mu \mathrm{s}$ の超音波パ ルスを出力する.

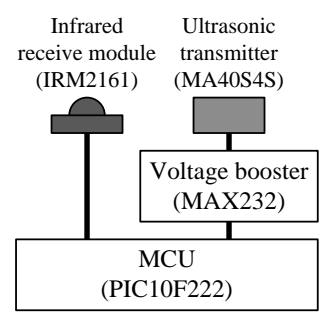

図 6 超音波送信部の構成

Fig. 6 Configuration of ultrasonic transmit unit

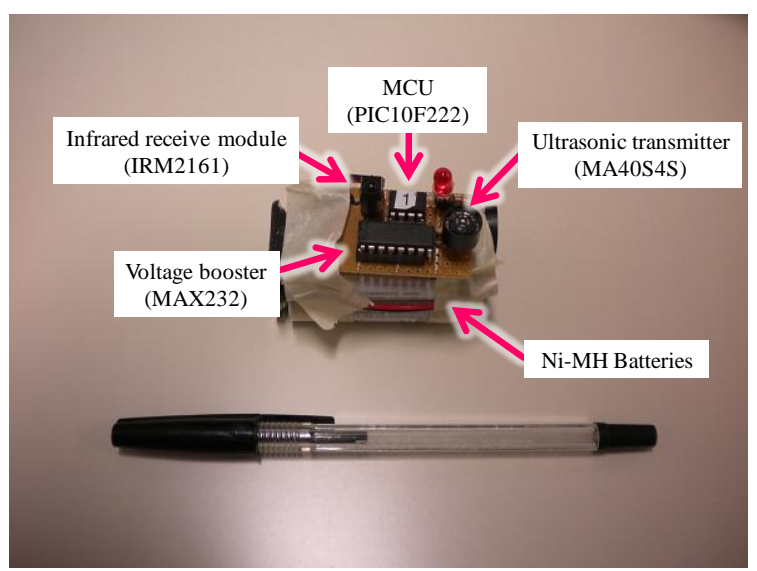

図 7 超音波送信部の概観

Fig. 7 Overview of ultrasonic transmit unit

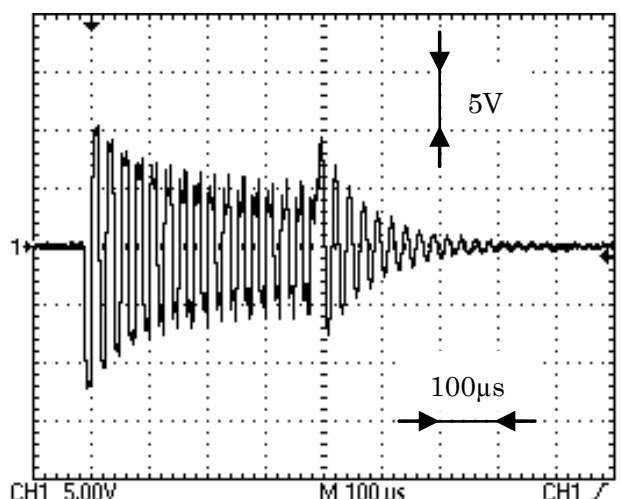

図 8 超音波送信波形

Fig. 8 Ultrasonic transmit waveform

3.4 超音波受信部の設計と実装＼cjkstart超音波受信部の内部構 成を図 9 に示寸，超音波受信部の各機能は図 10 に示寸メ イン基板，図 11 に示寸超音波センサ，図 12 に示寸増幅・ 検波回路, 図 14 に示寸赤外線送信機に分けて実装した.

メイン基板には, 処理用 PC とのインタフェースを行う マイコン（Renesas H8/3052F）と超音波の受信タイミング の検出を行う FPGA (Altera EP2C8Q208) を搭載している. 超音波の受信可能距離を最大 $7 \mathrm{~m}$ 程度とするため, マイコ ンと FPGAは共通のクロック (25MHz) で動作させ, FPGA 内部ではこれをさらに 8 分周した $3.125 \mathrm{MHz}$ で $16 \mathrm{bit}$ の内 部タイマカウンタをインクリメントすることとした。 FPGA は，内部カウンタがオーバーフローするまでの約 $21 \mathrm{~ms}$ 間に超音波の受信を検出すると，受信チャネルごと に用意したレジスタに内部カウント值をキャプチャする. このカウント值から処理用 PC で式(1)の $t_{i}$ を算出する. ま た，音速の温度補償用サーミスタを実装した。さらに，超 音波受信部を RS-485 によって複数台接続することで測位 エリアを拡大寸るため, メイン基板上に超音波受信部を識 別するための局番設定用 DIP スイッチを実装した.

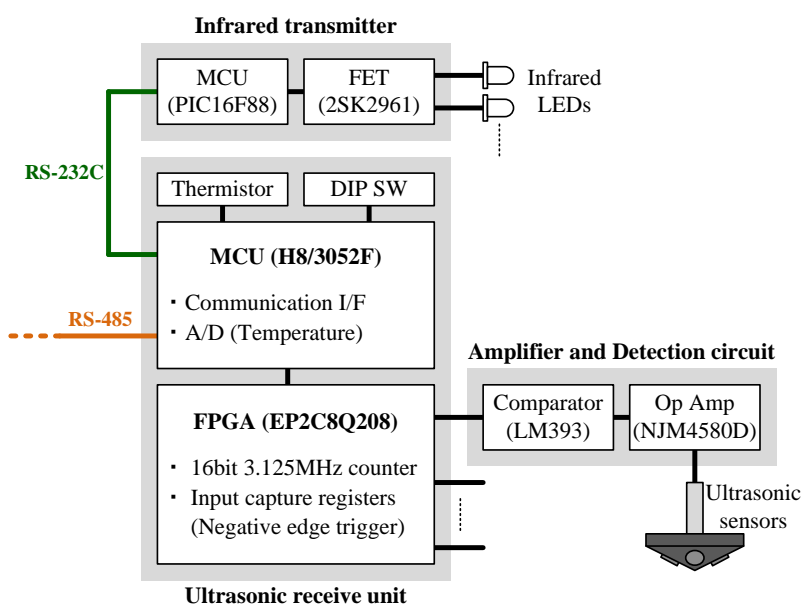

図 9 超音波受信部の構成

Fig. 9 Configuration of ultrasonic receive unit 


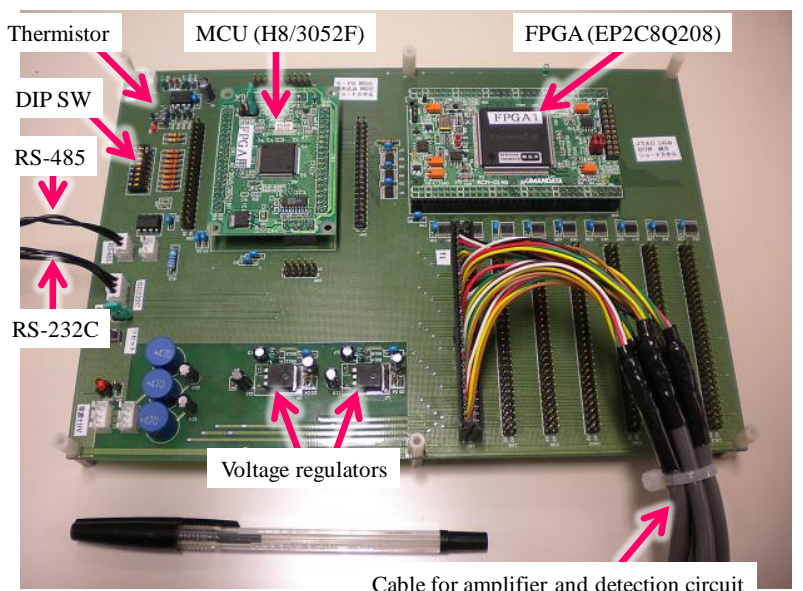

図 10 超音波受信部の概観（メイン基板）

Fig. 10 Overview of ultrasonic receive unit (Main board)

次に，超音波センサと増幅・検波回路について述べる． 超音波センサの概観を図 11 に示寸。センサの設置間隔は 送受信機間の距離に依存するが, 受信チャネル 1ch あたり 1 個のセンサの夕を用いる場合, 受信指向性に限界がある ためセンサの設置間隔を広げることができない，そこで， 受信チャネル 1ch あたり 4 個のセンサを接続し, それぞれ を四角錐状に配置することによって 1 チャネルあたりの 指向性を拡大寸ることとした[13]. 超音波センサで検出し た超音波パルスは, 図 12 に示寸増幅・検波回路を介して FPGA に入力する. 増幅 - 検波回路では微弱な超音波信号 を増幅し, 図 11 に示す 4 個のセンサの出力を合成して, 図 13 に示寸出力信号を生成する。この例では超音波送信 部から出力された直接波のほかに, 室内の家具などによる 反射波がみられる。試作装置では，カウントを開始してか ら最初の出力信号の変化のみを検出することで, 反射波の 影響を取り除いている.

最後に赤外線送信装置について述べる. 赤外線送信装置 の概観を図 14 に示す。赤外線送信装置はマイコンから RS-232C を介して送信される命令をもとにして, 図 15 に

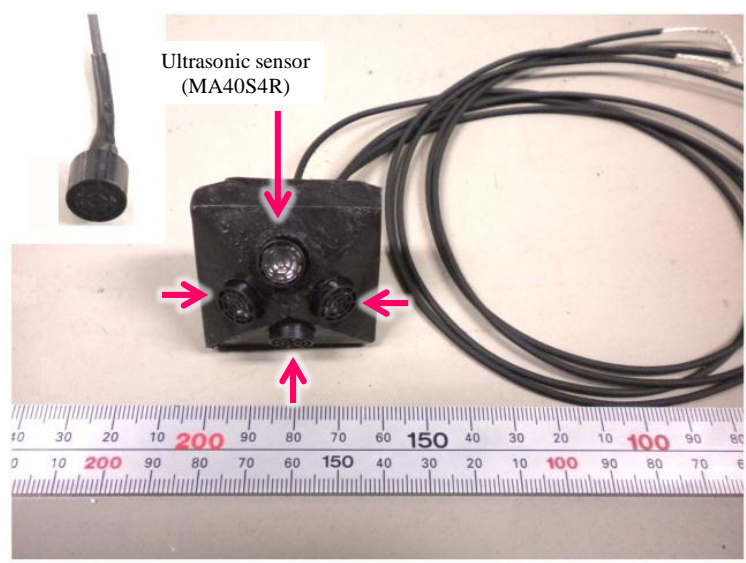

図 11 超音波センサの概観

Fig. 11 Overview of ultrasonic sensors
示す赤外線信号を出力する。この図は論理波形であり， LED から出力する信号は一般的な家電用のリモコンと同 様[14]に $38 \mathrm{kHz}$ の副搬送波で変調を行う。赤外線信号は, 信号開始を表すリーダ部, 超音波送信部を特定するための ID 部，信号終了を表すトレーラ部からなり，ID 部は単位 パルス長 $600 \mu \mathrm{s}$ のPP で符号化した.

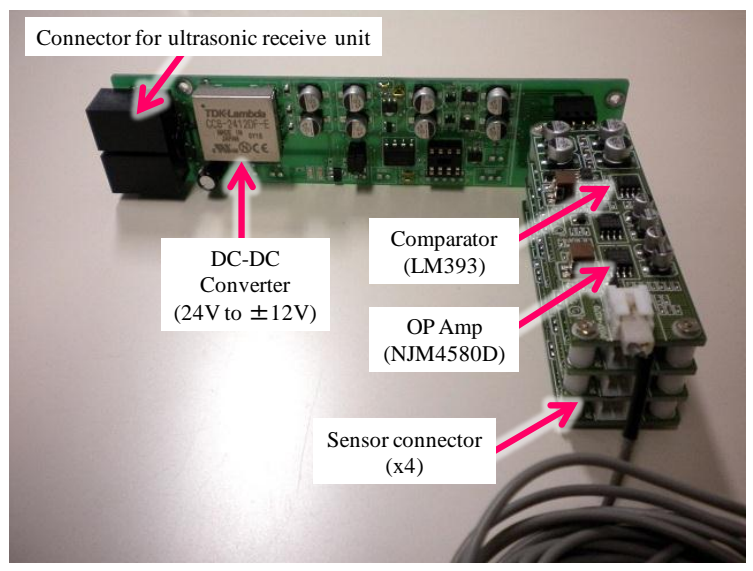

図 12 増幅 - 検波回路の概観

Fig. 12 Overview of amplifier and detection circuit

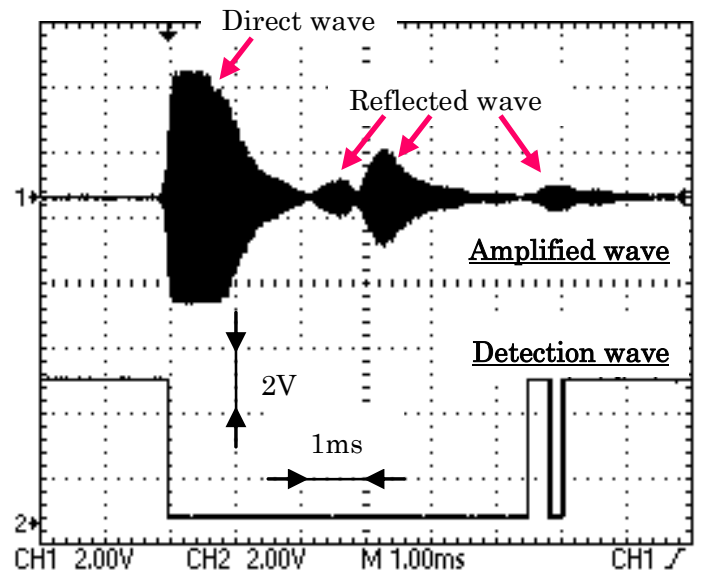

図 13 増幅・検波後の超音波波形

Fig. 13 Ultrasonic waveform after amplifier and detection

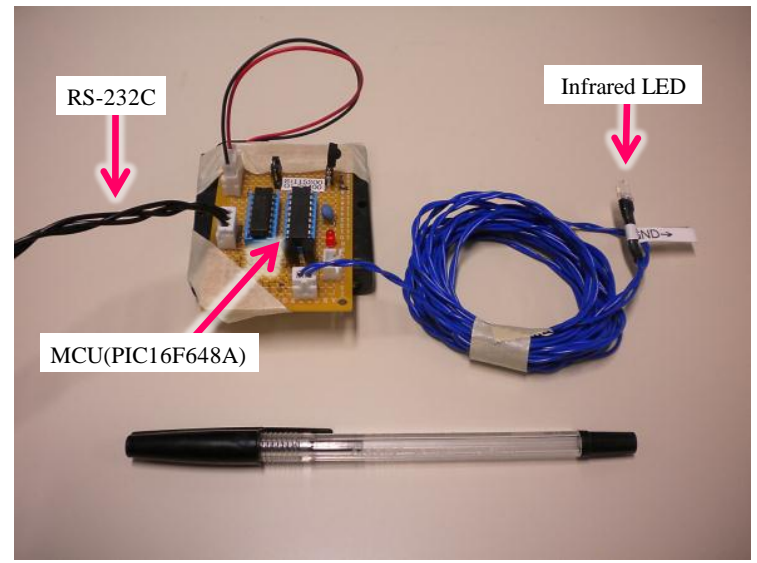

図 14 赤外線送信装置の概観

Fig. 14 Overview of infrared transmitter 


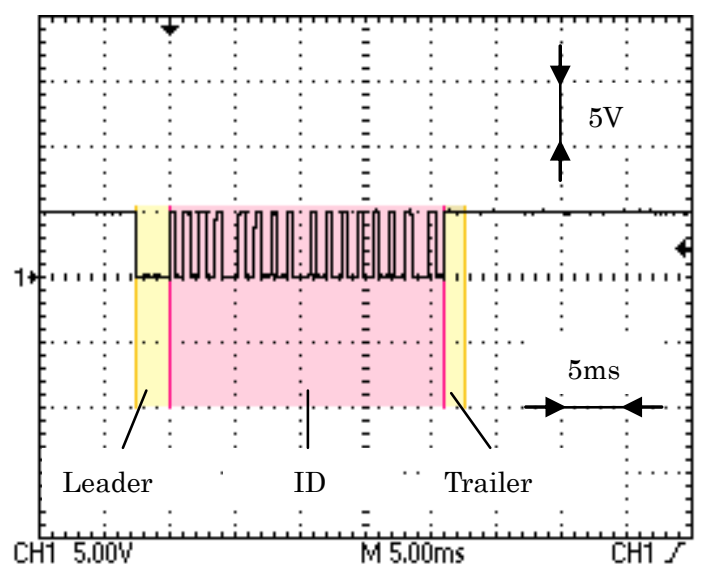

図 15 赤外線信号波形

Fig. 15 Infrared signal waveform

\section{4. システム評価実験}

4.1 実験系の構成 試作した検証システムの機能と測位 精度を確認するため, 図 16 に示すように, 実利用を想定 して建物の天井に超音波受信センサを複数設置し, システ ムの評価実験を行った. 実験環境の天井高さは $2600 \mathrm{~mm}$ で, 天井の石膏ボードに穴あけ加工を行い, 表 1 に示す座標に センサを設置した．ここで，床面を xy 平面としている. 超音波センサと赤外線 LED の設置状況を図 17 に示す. 天 井裏のセンサ直近には増幅・検波回路を配置し, 実験環境 の壁際に置いたラック上の超音波受信部まで隠蔽配線を 行った. 実環境中に設置した際の機能および測位精度評価 を主な目的としたため, 測位範囲は約 $3 \mathrm{~m} \times 3 \mathrm{~m}$ に限定した.

本実験では, 静止物体の測位と移動物体の測位の両方を 評価対象とした. 静止物体の測位では, 超音波送信部をセ ンサ Ch.4 の直下 $(1200,1200,0)$ に置いて測位を行った. 移動物体の測位では, 図 18 に示す正方形のレール上を $0.5 \mathrm{~m} / \mathrm{s}$ 程度で走行する 2 台の模型列車にそれぞれ超音波送 信部を取り付けて測位を行った.いずれも送信部 1 台あた り約 1 秒間隔で測位し，これを 3 分間連続して行った.

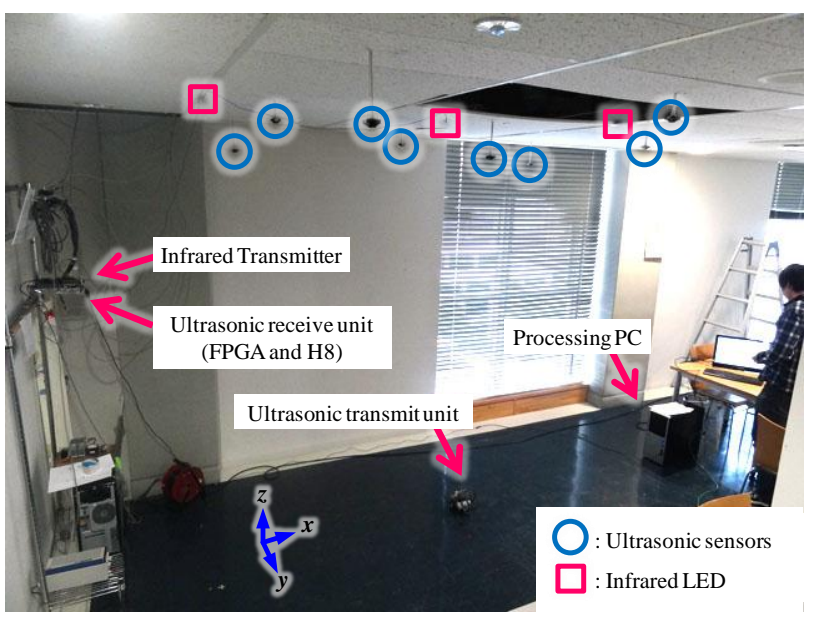

図 16 実験構成（全体図）

Fig. 16 Experiment configuration (general view)

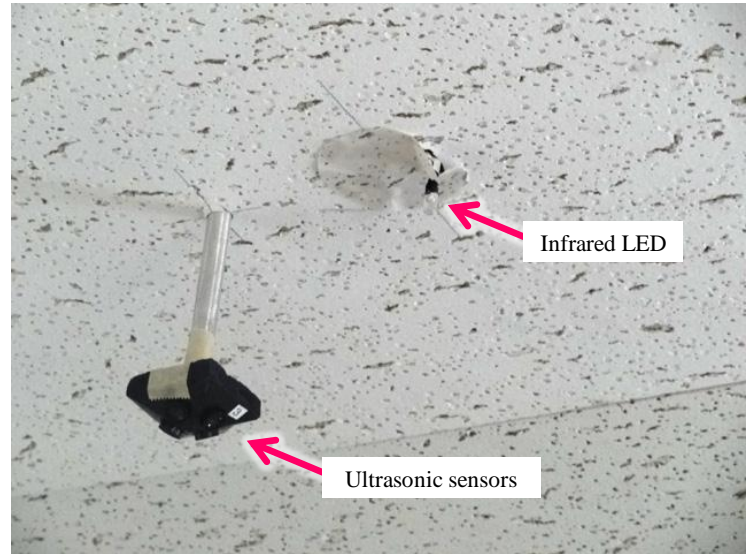

図 17 超音波センサの設置状況

Fig. 17 Installation of ultrasonic sensors

表 1 実験時の超音波センサ配置

Table 1 Ultrasonic sensors locations for experiment

\begin{tabular}{c|c|c|c}
\hline Sensor Ch. & $\boldsymbol{x}[\mathbf{m m}]$ & $\boldsymbol{y}[\mathbf{m m}]$ & $\boldsymbol{z}[\mathbf{m m}]$ \\
\hline 0 & 0 & 0 & 2400 \\
\hline 1 & 1200 & 0 & 2500 \\
\hline 2 & 2400 & 0 & 2400 \\
\hline 3 & 0 & 1200 & 2500 \\
\hline 4 & 1200 & 1200 & 2400 \\
\hline 5 & 2400 & 1200 & 2500 \\
\hline 6 & 0 & 2400 & 2400 \\
\hline 7 & 1200 & 2400 & 2500 \\
\hline 8 & 2400 & 2400 & 2400 \\
\hline
\end{tabular}

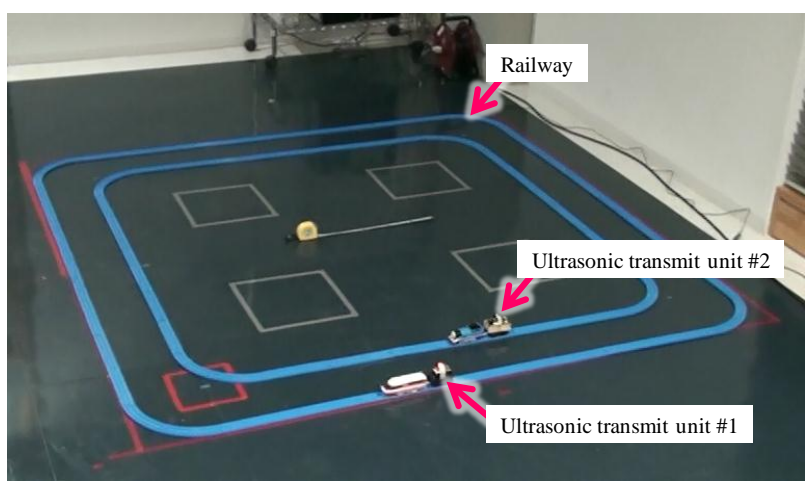

図 18 実験構成（移動物体）

Fig. 18 Experiment configuration (mobile object)

4.2 実験結果と評価 静止物体を対象とした場合の測位 結果を図 19 に示す. 実際の位置と測位結果とのオフセッ 卜誤差は平均 $42 \mathrm{~mm}$ ，標準偏差は $0.6 \mathrm{~mm}$ であり，屋内測 位アプリケーションへの適用に対して十分な測位精度が 確保されていることを確認した．なお，この誤差の要因と して，センサ設置における取り付け誤差の影響[15]や測位 計算の初期值の影響などが考えられる. 


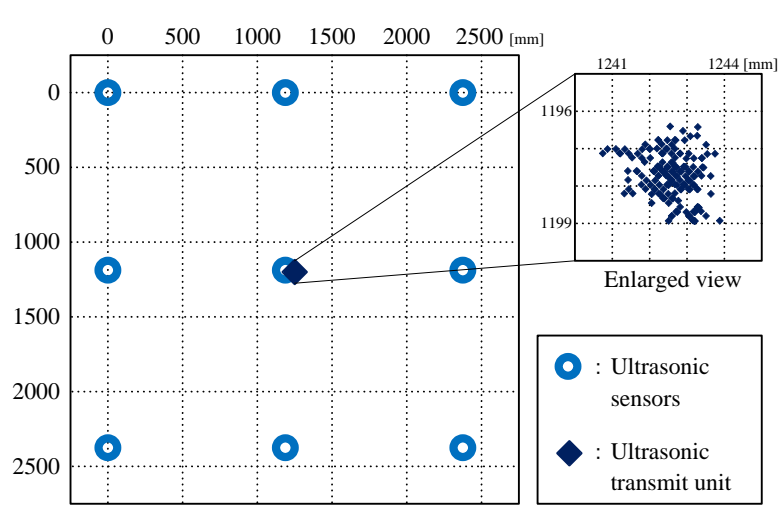

図 19 実験結果（静止物体）

Fig. 19 Experiment result (stationary object)

次に, 2 個の移動物体を対象とした場合の測位結果を図 20 に示す。それぞれの測位対象が識別されていること, また，測位誤差が最大でも $100 \mathrm{~mm}$ 程度であり，概ねレー ルの形状に一致して測位されていることから, 複数対象の 測位が可能であり, 測位対象が移動している場合でも測位 精度に大きな影響がなく, 数 $100 \mathrm{~mm}$ 程度の要求精度に対 して十分な結果が得られることを確認した。

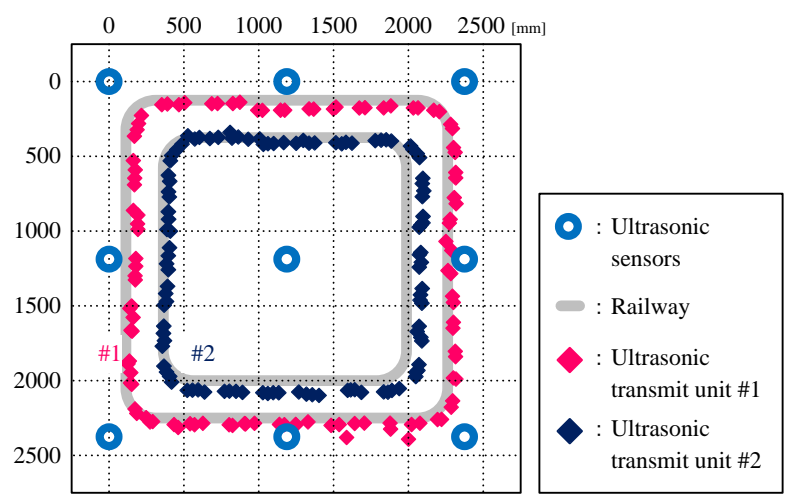

図 20 実験結果（移動物体）

Fig. 20 Experiment result (mobile object)

\section{5. ナビゲーション模擬実験}

5.1 実験系の構成 検証システムの有用性を確認するた め, 図 21 に示す小型の移動ロボットと実験環境を用いた 歩行者ナビゲーションの模擬実験を行った. 本実験の手順 について述べる。まず，測位エリアの床面に幅 $500 \mathrm{~mm}$ の 通路を田の字型に設定し, その曲がり角を経路探索用のノ ードとする. 次に, 超音波送信部を取り付けた移動ロボッ 卜を通路上の任意の初期位置に置き,ここから任意の目的 地点に至る最短経路をダイクストラ法によって探索 [16] する. そして, 約 1 秒間隔で測位を行い, ロボットの現在 位置から探索経路上の次に進むべきノードの方向を $45^{\circ}$ 刻みで求め，処理用 PC から Bluetooth によってロボット の移動制御を行う。ロボットは $100 \mathrm{~mm} / \mathrm{s}$ 程度で直進走行 させ, 方向転換するときは左右のモータの回転数を変化さ せることとした.

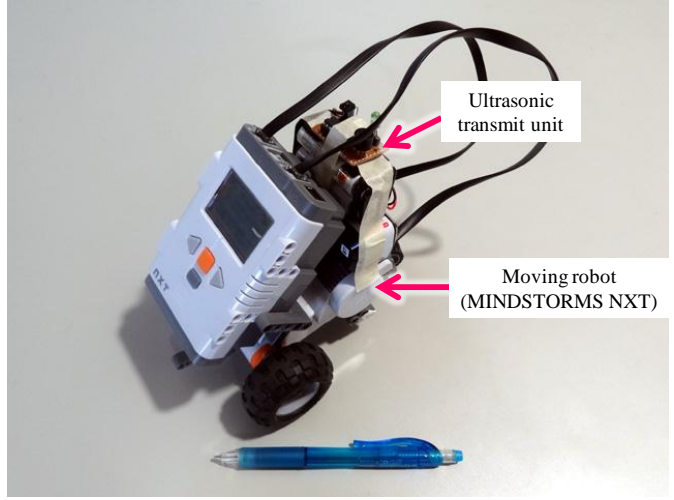

図 21 移動ロボットの概観

Fig. 21 Overview of moving robot

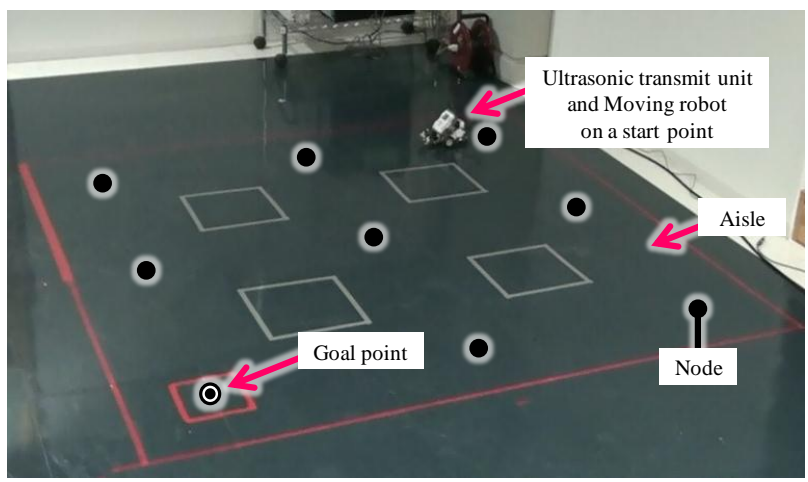

図 22 実験構成

Fig. 22 Experiment configuration

5.2 実験結果と評価 ナビゲーション模擬実験の結果を 図 23 に示す。図中の太線（一）はノードを経由する初期 位置から目的地点までのダイクストラ法によって求めた 最短経路である.この経路上を走行するようにナビゲーシ ヨンを行い，ロボットが走行した軌跡を図中に菱印（•） で示す.ロボットが初期位置から目的地点まで通路を逸脱 することなく探索経路上を走行していることから,ナビ年 ーション手法の妥当性とともに構築した検証システムの 有用性を確認することができ, 提案システムに受信回路を 追加して測位エリアをさらに広域化することによって, 歩行者へのナビゲーションに適用できる見通しを得た。

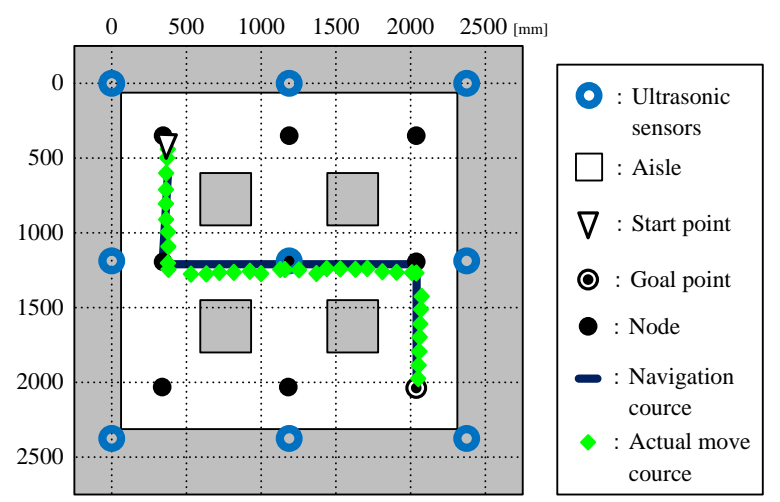

図 23 実験結果（ナビゲーション）

Fig. 23 Experiment result (navigation) 


\section{6. むすび}

屋内測位システムとして，超音波のみで測位が可能な 方法を用いるとともに, 実利用を考慮して複数測位対象の 識別と測位エリアの拡大が容易なシステムついて検討を 行った。 そして, 実際に検証システムを試作し, 実利用を 想定した環境に設置して機能評価および測位精度評価実 験を行った. その結果, 数 $100 \mathrm{~mm}$ 以内の精度が要求され る屋内測位アプリケーションへの適用に対して十分な精 度が確保されていることが確認できた. また, 歩行者のナ ビゲーションを想定し, 小型の移動ロボットを対象として 経路探索および移動制御を行い, ナビゲーションの模擬実 験を行った. その結果, 試作した検証システムの有用性を 確認するとともに, 今後, 測位エリアをさらに広域化する ことによって, 屋内ナビゲーションに適用できる見通しを 得た.

(平成 24 年 2 月 23 日受付, 4 月 12 日再受付)

\section{文 献}

[1] 別所正博, 小林真輔, 越塚登, 坂村健, "ユビキタスコンピュ ーティングと屋内環境の位置認識", 電子情報通信学会誌, Vol.92, No.4, pp.249-255, 2009.

[2] 木下泰三, 荻野敦, "無線 LAN と UWB $の$ Indoor 測位", 測位航 法学会 GPS/GNSS シンポジウム 2010, pp.94-101, 2010.

[3] 村田正秋, 瀬川爾朗, 鳥本秀幸, "IMES の技術動向", 電子情 報通信学会誌, Vol.95, No.2, pp.119-124, 2012.

[4] 宇宙航空研究開発機構, 測位衛星技術株式会社, "準天頂衛星 システムと地上補完システムIMES", 経済産業省 地理空間 情報活用推進研究会, 第 5 回 資料 1, 11pages, 2008.

[5] 秋山征己, 羽田昂史, 須永光, 五百蔵重典, 田中博, "超音波を 用いた屋内測位システムにおける広域化と複数対象識別方法 の検討と実証", 電気学会 IS 研究会, IS-10-59, pp.49-54, 2010.

[6] Takashi Hada, Hikaru Sunaga, Masaki Akiyama, Shigenori Ioroi, and Hiroshi Tanaka, "Investigation and Demonstration of Local Positioning System using Ultrasonic Sensors for Wide Indoor Areas", International Conference on Ambient Intelligence 2010, pp.280-284, 2010.

[7] Adam Smith, Hari Balakrishnan, Michel Goraczko, and Nissanka Priyantha, "Tracking Moving Devices with the Cricket Location System", ACM MobiSYS 2004, 13 pages, 2004.

[8] Mike Addlesse, Rupert Curwen, Steve Hodges, Joe Newman, Pete Steggles, Andy Ward, and Andy Hopper, "Implementing a Sentient Computing System", IEEE Computer, August 2001, pp.2-8, 2001.

[9] 川下勝平,"古河機械金属株式会社 超音波式 3 次元トラッカー ZPS-VK", 日本 VR 学会誌, Vol.11, No.1, pp.50-51, 2006.

[10]本間裕介, 森谷潤一郎, 長谷川孝明, "可聴音波及び超音波を 用いた逆 GPS 方式位置特定システムの比較実験", 電子情報 通信学会論文誌 A, Vol.J91-A, No.1, pp.139-142, 2008.
[11] 坂井丈泰, "GPS のための実用プログラミング", 東京電機大 学出版局, pp.82-91, 2007.

[12] 山根章生, 伊与田健敏, 崔龍雲, 久保田譲, 渡辺一弘, "疑似乱 数 $\mathrm{M}$ 系列によるスペクトラム拡散音波の距離計測への応用", 計測自動制御学会論文集, Vol.39, No.10, pp.879-886, 2003.

[13]羽田昂史, 須永光, 秋山征己, 五百蔵重典, 田中博, "超音波 センサを用いた屋内測位システムにおける測位エリア拡大の 検討", DICOMO2011, 5F-1, pp.915-920, 2011.

[14]栊川友宏, "家電用ユニバーサル赤外線モデム Uni-REMOTE の設計と開発", 映像情報メディア学会技報, Vol.34, No.32, pp.19-24, 2010.

[15]須永光, 羽田昂史, 秋山征己, 五百蔵重典, 田中博, "超音波を 用いた屋内測位システムにおける誤差要因とその評価", FIT2010, M-054, pp.393-394, 2010.

[16]相川直樹, 須永光, 小松仁輝, 秋山征己, 五百蔵重典, 田中博, "超音波測位システムを用いた屋内ナビゲーションに関する 基本検討", 電子情報通信学会 HCG シンポジウム 2010, B5-3, pp.206-211, 2010.

\section{著者紹介}

秋山 征己（学生員） 2011 年神奈川工科大学情報工学科 卒. 現在, 同大学大学院博士前期課程在学中. 主として屋内 測位システムや家電ネットワーク制御に関する研究に従事. 電子情報通信学会の学生員.

須永 光（非会員） 2010 年神奈川工科大学情報工学科卒. 2012 年同大学大学院博士前期課程修了. 同年 (株)ジャパン プランニング入社. 在学中は主として屋内測位システムや慣 性センサを用いた自律航法に関する研究に従事.

五百蔵 重典（非会員）1993 年東京理科大学理学部応用 数学科卒. 同年 (株) PFU 入社 ( 1995 年). 1999年北陸先端 科学技術大学院大学博士課程後期修了. 同年神奈川工科 大学情報工学科助手. 2008 年〜同大学准教授. 現在, ソフト ウェア工学, ユビキタスシステムおよび入力インタフェースのデ ザインとその実証に関する研究に従事. 情報処理学会, ソフト ウェア科学会, ACM の会員. 博士 (情報科学).

田中 博 (正員) 1983 年北海道大学工学部精密工学科卒. 1985 年同大学大学院工学研究科修士課程修了. 同年日本 電信電話 (NTT) 入社. 以来, 衛星通信用搭載機器および衛 星通信システムに関する研究開発に従事. 1994～1997 年ま で宇宙開発事業団 (現宇宙航空研究開発機構)に出向. 2006 年〜神奈川工科大学情報工学科教授. 現在, ユビキタスシス テムデザインとその実証に関する研究に従事. 電子情報通信 学会, 情報処理学会, 航空宇宙学会, AIAA などの会員. 博士 (工学). 